\title{
Abundance, vertical distribution and life cycle patterns of the hydromedusa Aglantha digitale in the Oyashio region, western subarctic Pacific
}

\author{
Daisuke TAKahashi \& TSUTOMU IKedA* \\ Marine Biodiversity Laboratory, Graduate School of Fisheries Sciences, Hokkaido University, 3-1-1 Minato-machi, Hakodate, \\ Hokkaido, 041-0821 Japan
}

Received 2 September 2005; Accepted 25 January 2006

\begin{abstract}
Analyses of monthly depth-stratified (0-2000 m) sampling data in the Oyashio region have revealed that Aglantha digitale is distributed largely in the upper $250 \mathrm{~m}$ throughout the year. Population biomass ranged from $<30 \mathrm{mg} \mathrm{DW} \mathrm{m}^{-2}$ (January) to $1575 \mathrm{mg} \mathrm{DW} \mathrm{m}^{-2}$ (August), with an annual mean of $186 \mathrm{mg} \mathrm{DW} \mathrm{m}^{-2}$. Judging from seasonal sequences of the population structure, the generation length of $A$. digitale is considered to be one year with their spawning season in June-September, which is consistent with that observed at Station P in the eastern subarctic Pacific.
\end{abstract}

Key words: Aglantha digitale, vertical distribution, life cycle, Oyashio, North Pacific

\section{Introduction}

Aglantha digitale is a holoplanktonic hydromedusa distributed through circumpolar arctic waters (Kramp 1959; 1965), and is a common zooplankton component in the subarctic Pacific (Arai \& Fulton, 1973; Hirohashi 1988) and Atlantic Oceans (González \& González 1996; Søreide et al. 2003). While young $A$. digitale ( $4-5 \mathrm{~mm}$ ) ingest diatoms, tintinnids, radiolarians and copepod nauplii, old ones $(>5 \mathrm{~mm})$ are typical ambush-predators and feed on copepods and chaetognaths (Smedstad 1972; Hirohashi 1988; Pagès et al. 1996; Colin et al. 2003). Information about predators on A. digitale is currently limited; Tsuruta (1963) found this medusa in the stomach of the chum salmon Onchorhynchus keta, and Runge et al. (1987) observed ready ingestion of $A$. digitale by the Atlantic mackerel Scomber scombrus in the laboratory. Rapid digestion of gelatinous zooplankton in the stomach of fishes may have been masking the importance of this group of animals in the trophodynamics of pelagic systems (cf. Arai et al. 2003). The above results suggest possible trophic importance of $A$. digitale in the pelagic ecosystem of the subarctic Pacific Ocean, but information about their life cycle patterns, as a basis to estimate trophic impacts of this medusa, is currently limited to the population at Station $\mathrm{P}$ in the eastern

* Corresponding author: Tsutomu Ikeda; E-mail, tom@pop.fish.hokudai. ac.jp subarctic Pacific (Arai \& Fulton 1973).

As part of a research program to evaluate plankton dynamics in the western subarctic Pacific, the present study aims to investigate the abundance, vertical distribution and life cycle patterns of Aglantha digitale in the Oyashio region, by analyzing time-series samples collected from 5 discrete depths between 0 and $2000 \mathrm{~m}$. The present results are compared with those in the eastern subarctic Pacific and other regions.

\section{Methods}

Monthly depth-stratified sampling was done in the Oyashio region $\left(41^{\circ} 30^{\prime}\right.$ to $42^{\circ} 30^{\prime} \mathrm{N}$ and $145^{\circ} 00^{\prime}$ to $\left.146^{\circ} 00^{\prime} \mathrm{E}\right)$ off southeastern Hokkaido (hereafter referred to as Site H, Fig. 1). Zooplankton were collected with a closing net $(60 \mathrm{~cm}$ mouth diameter, $100 \mu \mathrm{m}$ mesh size; Kawamura 1968) equipped with a Rigosha flow-meter in its mouth ring and a TSK depth distance recorder (Tsurumi Seiki Co. Ltd.) or RMD depth meter (Rigosha Co. Ltd.) on its suspension cable. The net was towed vertically at a speed of $1 \mathrm{~m} \mathrm{~s}^{-1}$, usually through five discrete depths: 0 (surface) to the bottom of the thermocline (BT), BT-250 m, 250$500 \mathrm{~m}, 500-1000 \mathrm{~m}$ and $1000-\leq 2000 \mathrm{~m}$ (Table 1). During the winter season when the thermocline was not recognized, BT was assumed arbitrarily to be at $100 \mathrm{~m}$ depth. After collection, zooplankton samples were immediately preserved in $5 \%$ formalin-seawater solution buffered with borax. 


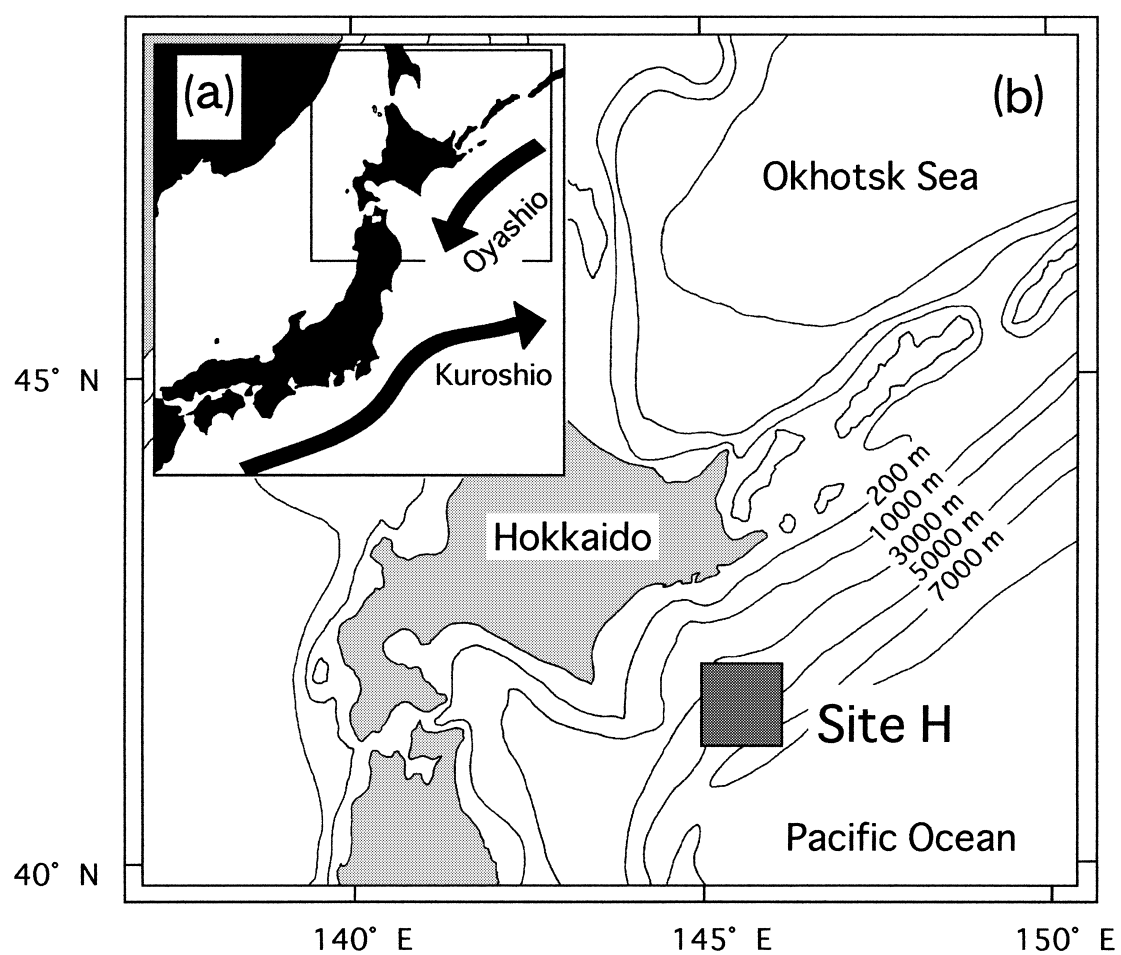

Fig. 1. The Oyashio region in the western subarctic Pacific Ocean (a) and the sampling site ("Site H", shaded)(b). Depth contours $(200,1,000,3,000,5,000$ and 7,000 $\mathrm{m})$ are superimposed in (b).

Table 1. Zooplankton sampling data at Site H in the Oyashio region (N: nighttime, D: daytime, Os: TS "Oshoro Maru", Ho: TS "Hokusei Maru”, Hs: RV “Hokusin Maru”, Hk: "Hokko Maru”, Ts: RV “Tansei Maru”)

\begin{tabular}{llll}
\hline Sampling date & Time & Ship & \multicolumn{1}{c}{ Discrete sampling depths $(\mathrm{m})$} \\
\hline 4 Sep. 1996 & D/N & Os & $0-30,30-250,250-500,500-1000,1000-1800$ \\
19 Sep. 1996 & N & Ho & $0-30,30-250,250-500,500-1000,1000-1500$ \\
2 Oct. 1996 & D & Ho & $0-30,30-250,250-500,500-1000,1000-1500$ \\
8 Dec. 1996 & D/N & Hs & $0-80,80-250,250-500,500-1000,1000-1700$ \\
13 Jan. 1997 & D & Hk & $0-50,10-500,300-1700$ \\
20 Feb. 1997 & N & Hs & $0-100,100-250,250-500$ \\
17 Mar. 1997 & N & Hk & $0-100,100-250,250-500,500-1000,1000-2000$ \\
11 Apr. 1997 & D/N & Ho & $0-100,100-250,250-500,500-1000,1000-1500$ \\
7 May 1997 & N & Hk & $0-100,100-250,500-1000,1000-2000$ \\
4 Jun. 1997 & N & Os & $0-80,80-250,250-500,500-1000$ \\
23 Jun. 1997 & N & Ho & $0-20,20-250,250-500,500-1000,1000-2000$ \\
2 Jul. 1997 & N & Ho & $0-40,40-250,250-500,500-1000,1000-2000$ \\
17 Aug. 1997 & N & Os & $0-80,80-250,250-500,500-1000,1000-2000$ \\
26 Aug. 1997 & D & Ts & $0-20,20-250,250-500,500-1000,1000-2000$ \\
5 Oct. 1997 & D/N & Ho & $0-75,75-250,250-500,500-1000,1000-2000$ \\
\hline
\end{tabular}

Temperature and salinity profiles were determined with a CTD system at each zooplankton sampling. Chlorophyll $a$ profiles at Site $\mathrm{H}$ have been reported elsewhere (Kasai et al. 2001). In the land laboratory, Aglantha digitale was sorted from the entire samples and counted under a dissecting microscope. Bell height $(\mathrm{BH} ; \mathrm{mm})$ was measured under the dissecting microscope to the nearest $0.1 \mathrm{~mm}$. Specimens with "sausage" shaped gonads greater than $10 \%$ of $\mathrm{BH}$ were designated as "mature", and those $\leq 10 \%$ of $\mathrm{BH}$ as "immature" in this study (cf. McLaren 1969). In order to estimate the population biomass in terms of dry weights (DW; mg), BH data for each specimen was converted to DW data by using an allometry equation: $\log _{10} \mathrm{DW}=$ $0.454\left(\log _{10} \mathrm{BH}\right)^{2}+1.883 \log _{10} \mathrm{BH}-2.402 \quad\left(\mathrm{r}^{2}=0.977, \quad \mathrm{~N}=41\right.$, $\mathrm{p}<0.001$; Takahashi \& Ikeda unpublished data). 


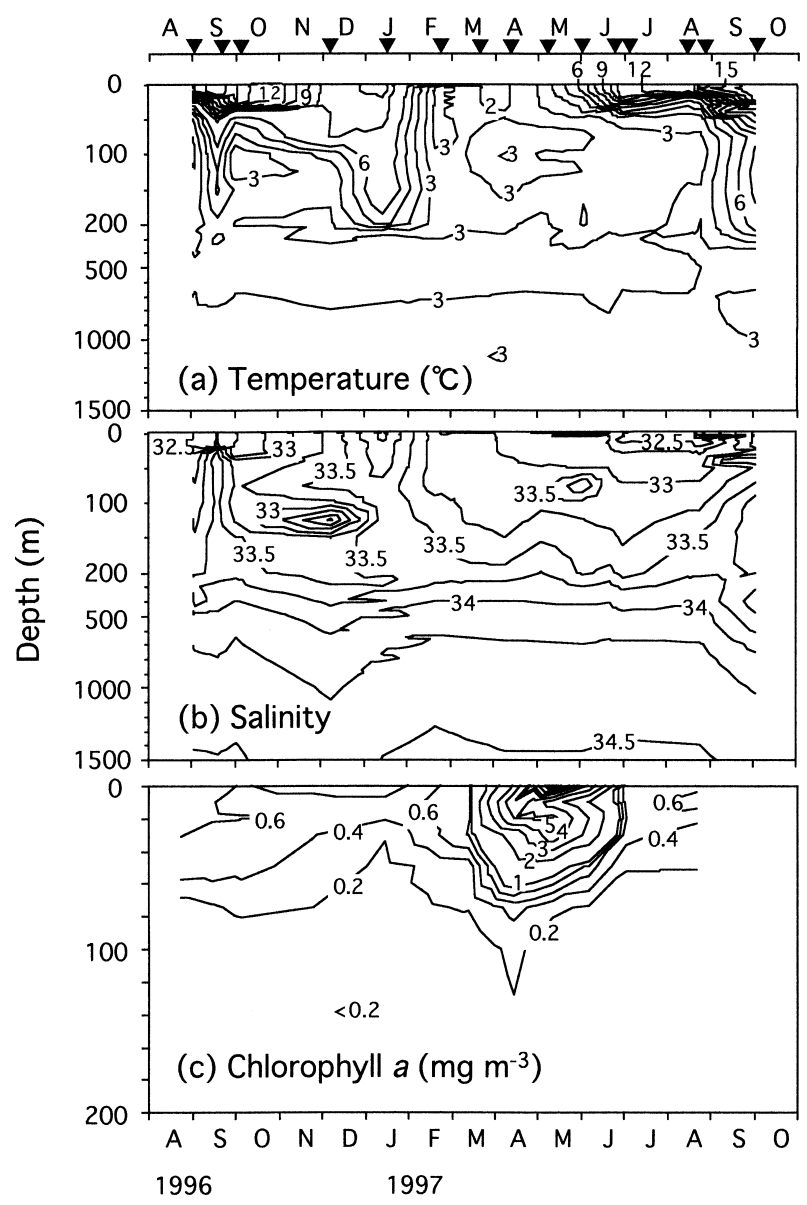

Fig. 2. Seasonal changes in vertical structures of temperature $\left({ }^{\circ} \mathrm{C}\right.$, top panel), salinity (middle panel) and chlorophyll $a$ concentration ( $\mathrm{mg} \mathrm{m}^{-3}$, bottom panel; after Kasai et al. 2001) at Site $\mathrm{H}$ from August 1996 to October 1997. Note that depth scale of the bottom panel is not the same to those of top two panels. Solid triangles on the abscissa denote sampling dates.

\section{Results}

Site $\mathrm{H}$ in this study is located near the southern end of the southwestward alongshore flow of the Oyashio Current. Over the study period, surface temperatures ranged from $2^{\circ} \mathrm{C}$ (March to April 1997) to $18^{\circ} \mathrm{C}$ (September to October 1996 and 1997) (Fig. 2). Oyashio Current water, characterized by salinities from 33.0 to 33.3 and temperatures below $3^{\circ} \mathrm{C}$ (Ohtani 1971), occurred in the upper $150 \mathrm{~m}$ from February to April 1997. After April, less saline, seasonally warmed water (possibly originating from the Okhotsk Sea; T. Kono pers. comm.) occupied the upper $50 \mathrm{~m}$ of the water column. Surface temperatures above $10^{\circ} \mathrm{C}$ were observed in September to November 1996 and in June to October 1997, when the thermocline was well established at 20 to $50 \mathrm{~m}$ in the water column. Effects of warm core rings originating from the Kuroshio extension were seen in September in both 1996 and 1997, and from December 1996 to January 1997 , as judged by temperature at $200 \mathrm{~m}\left(>4^{\circ} \mathrm{C}\right)$ and salinity in the 0 to $200 \mathrm{~m}$ layer $(>33.5)$ (Fig. 2). The tempera-

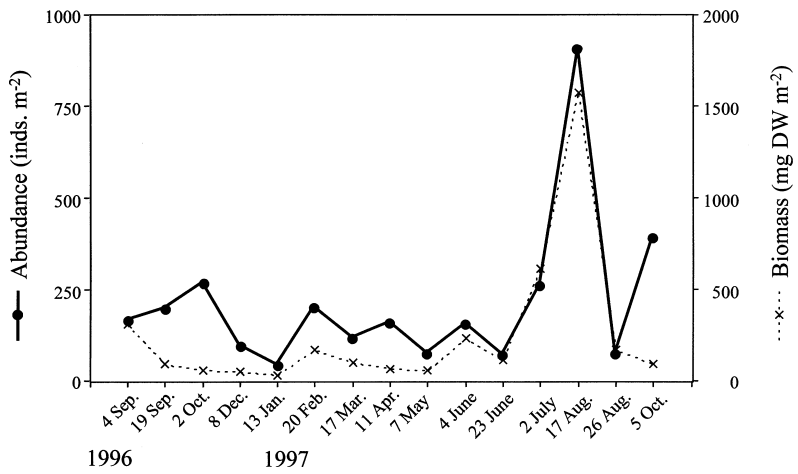

Fig. 3. Seasonal changes in numerical abundance and biomass of Aglantha digitale in $0-2000 \mathrm{~m}$ water column at Site $\mathrm{H}$ in the Oyashio region.

ture and salinity in the 200 to $1500 \mathrm{~m}$ layer were stable and nearly constant at 2 to $3^{\circ} \mathrm{C}$ and 33.5 to 34.5 , respectively, throughout the year. Phytoplankton biomass, estimated in terms of chlorophyll a concentrations, showed a marked seasonality (Fig. 2). Chlorophyll $a$ at the surface was around $0.4 \mathrm{mg} \mathrm{m}^{-3}$ from August 1996 to the end of February 1997, and increased rapidly to $>1 \mathrm{mg} \mathrm{m}^{-3}$ in mid March forming an annual peak of $>9 \mathrm{mg} \mathrm{m}^{-3}$ in May 1997. The surface chlorophyll $a$ concentrations had decreased to $2 \mathrm{mg} \mathrm{m}^{-3}$ by the end of June and to $0.4 \mathrm{mg} \mathrm{m}^{-3}$ toward the end of 1997. Chlorophyll $a$ concentrations were $<0.4$ $\mathrm{mg} \mathrm{m}^{-3}$ below $100 \mathrm{~m}$ depth throughout the year.

Aglantha digitale occurred throughout the year, with a mean abundance of 211 specimens $\mathrm{m}^{-2}$ over the entire study period (Fig. 3). The abundance during the period of December 1996 and May 1997 was low (55-259 specimens $\mathrm{m}^{-2}$ ), showing a consistent decreasing pattern with progress of the seasons. After that, the abundance increased rapidly, with an annual peak (896 specimens $\mathrm{m}^{-2}$ ) in August 1997. The seasonal change in population biomass paralleled that of abundance. The maximum was $1575 \mathrm{mgDWm}^{-2}$ in $\mathrm{Au}-$ gust, and the minimum $<30 \mathrm{mgDW} \mathrm{m}^{-2}$ in January, with a mean biomass of $186 \mathrm{mgDW} \mathrm{m}^{-2}$.

Differences in day/night vertical distribution patterns of Aglantha digitale on 4 September and 8 December 1996, and 11 April and 5 October 1997 (cf. Table 1) were all not significant (Kolmogorov-Smirnov tests, $\mathrm{p}>0.1$, data not shown). On this basis, only the night data for these sampling days were used to analyze seasonal changes in vertical distribution patterns (Fig. 4). All mature A. digitale were found in the top $250 \mathrm{~m}$ throughout the year. Part of the immature population resided below $250 \mathrm{~m}$ in early September (41\%) and December (41\%) in 1996, and January $(92 \%)$ and October $(66 \%)$ in 1997. It is noted that the broad distribution exceeding $1000 \mathrm{~m}$ depth in January 1997 may be an artifact due to the failure of stratified samplings (cf. Table 1).

The entire range of $\mathrm{BH}$ ( 1 to $23 \mathrm{~mm}$ ) of Aglantha digitale was divided into $1 \mathrm{~mm}$ increments (Fig. 5). The population structure of $A$. digitale was characterized by the predomi- 


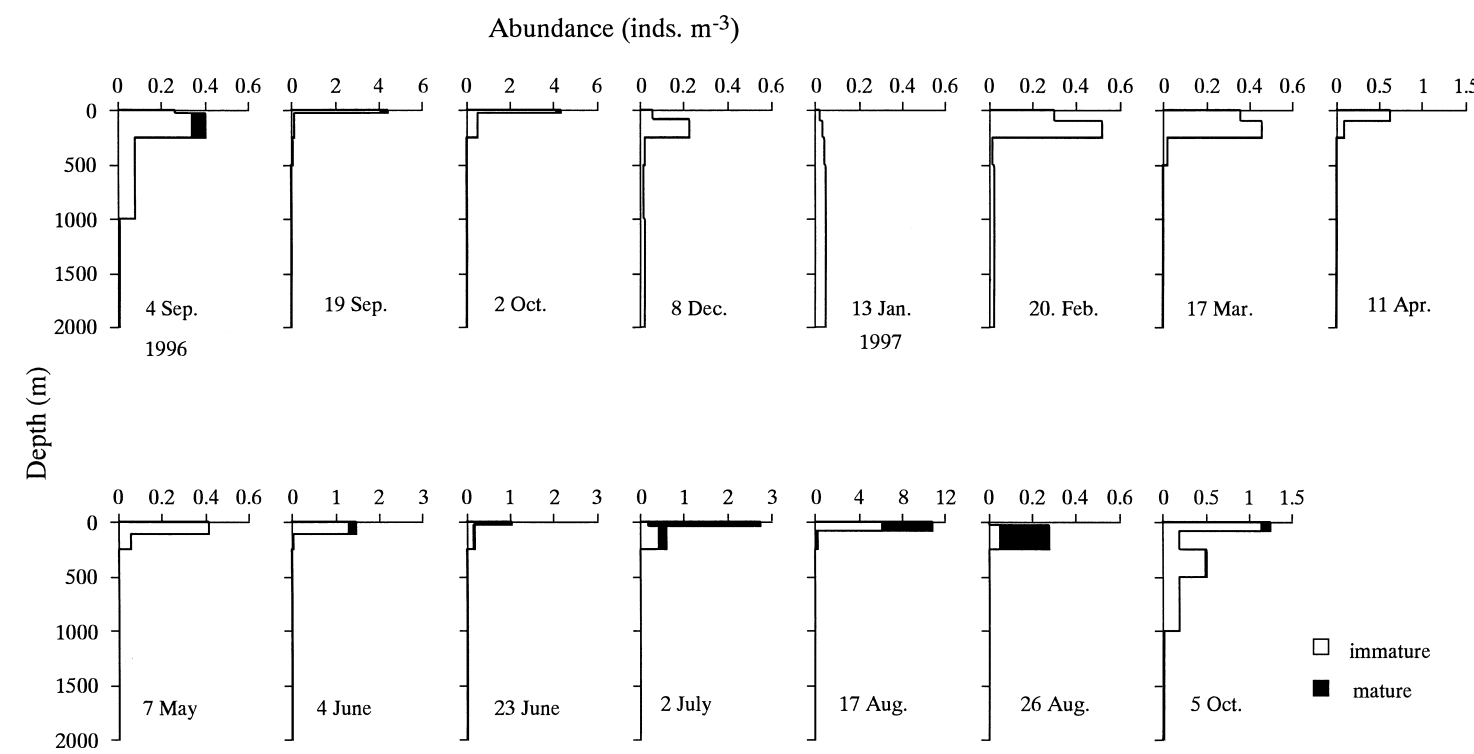

Fig. 4. Seasonal changes in vertical distribution of Aglantha digitale at Site $\mathrm{H}$ in the Oyashio region.

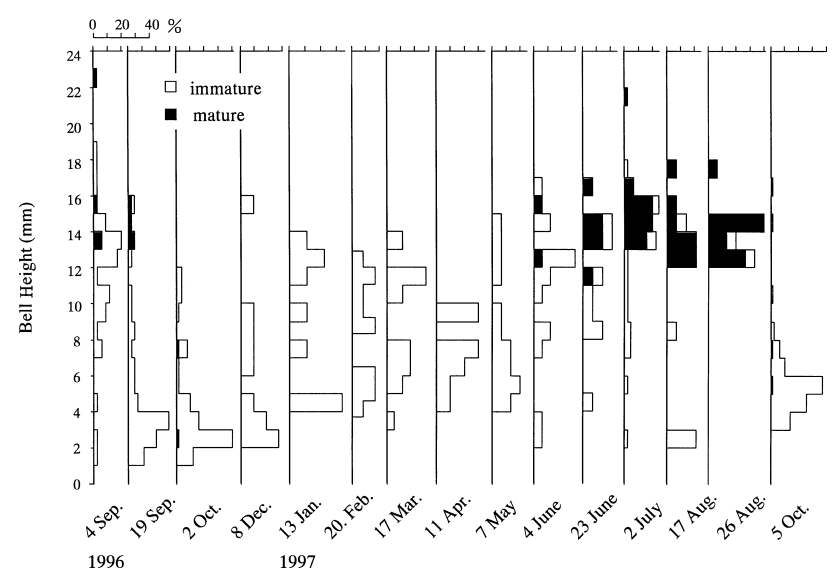

Fig. 5. Seasonal changes in population structure of Aglantha digitale in $0-2000 \mathrm{~m}$ water column at Site $\mathrm{H}$ in the Oyashio region.

nance of small $(<4 \mathrm{~mm} \mathrm{BH})$ immature specimens in September-December 1996, and by medium-sized (4-11 mm) immature specimens in January-May 1997. In June 1997 onward, large $(>11 \mathrm{~mm})$ mature specimens increased and occupied the major portion of the population. In October 1997, the large mature specimens disappeared and the small specimens occurred again. The minimum and maximum $\mathrm{BH}$ of the specimens recorded in this study was $1.4 \mathrm{~mm}$ and $22.5 \mathrm{~mm}$, respectively.

\section{Discussion}

The annual range of the abundance of Aglantha digitale recorded at Site $\mathrm{H}\left(55-896\right.$ specimens $\left.\mathrm{m}^{-2}\right)$ is in the same order of magnitude to that (10-500 specimens $\left.\mathrm{m}^{-2}\right)$ observed at Station P (Arai \& Fulton 1973), although the latter was based on the sampling of $0-150 \mathrm{~m}$ water column and specimens less than $5 \mathrm{~mm}$ were not taken into account. In the central subarctic Pacific, isolated abundance data (150-1500 specimens $\mathrm{m}^{-2}, 0-150 \mathrm{~m}$ depth) of $A$. digitale in June-August have been reported by Hirohashi (1988). In terms of population biomass, information comparable to the present results (annual mean: $186 \mathrm{mg} \mathrm{DW} \mathrm{m}^{-2}$ ) is only that $\left(225 \mathrm{mg} \mathrm{DW} \mathrm{m}^{-2}\right)$ for $A$. digitale in Toyama Bay studied by Ikeda \& Imamura (1996).

The vertical distribution of Aglantha digitale was largely limited to the upper $250 \mathrm{~m}$ at Site $\mathrm{H}$ throughout the year with a few exceptions of extended distribution down to $1000 \mathrm{~m}$ (Fig. 4). Recent observations by manned submersibles in the Kurile-Kamtchatka region (near Site $\mathrm{H}$ ) in July-August are consistent with the present results (e.g. the occurrence from the upper 200-250 m) (Vinogradov \& Shushkina 2002). In adjacent seas of the subarctic Pacific, the bathymetric distribution of $A$. digitale has been reported as in the upper 200 to $700 \mathrm{~m}$, depending on the season, in the Japan Sea (Zenkevitch 1963; Ikeda \& Imamura 1996), and the upper $200 \mathrm{~m}$ (no sampling below $200 \mathrm{~m}$ depth) in the summer of the southern Bering Sea (Hirohashi 1988). In the Northeastern Atlantic, Williams \& Conway (1981) studied the vertical distribution of this medusa over one year, and found that most of both smaller (1-3 mm BH) and larger specimens $(3-12 \mathrm{~mm}$ ) were in the top $100 \mathrm{~m}$ in May to August, and the latter extended distribution down to $500 \mathrm{~m}$ in July (no sampling was made at $>500 \mathrm{~m}$ ). These regional similarities and dissimilarities in the vertical distribution patterns of $A$. digitale may be interpreted as a result of complex attributes of physical conditions of the upper layers, decrease of food zooplankton abundance and possibly passive sinking behavior of this medusa in response to these environmental conditions (cf. review by Arai 1992).

Judging from the occurrence of mature specimens followed by smaller specimens (Fig. 5), the major spawning 
season of Aglantha digitale is deduced to be June- September at Site H. At Site H, June-September corresponds to the period of high abundance of young copepodids of grazing copepods such as Metridia pacifica (Padmavati et al. 2004), Neocalanus spp. (Kobari \& Ikeda 1999, 2001a, b), and Eucalanus bungii (Shoden et al. 2005), all of which grew rapidly in the upper layers through the phytoplankton bloom in mid March-June. Assuming that $A$. digitale is repeating the same life cycle pattern every year, the present results (Fig. 5) show that the new generation of $A$. digitale created in a given year overwinters and reaches maturity to spawn in June-September of the next year (e.g. annual life cycle), although tracing growth trajectory of the overwintering population is not very clear because of scatter in the size frequency data.

The comparison of the present results for Aglantha digitale at Site $\mathrm{H}$ with those at Station $\mathrm{P}$ in the eastern subarctic Pacific is of special interest to investigate possible regional variation in life cycle patterns of this medusa, as was made for large/medium grazing copepods such as Neocalanus spp. (Kobari \& Ikeda 1999, 2001a, b), Eucalanus bungii (Shoden et al. 2005) and Metridia spp. (Padmavati et al. 2004). The annual range in surface temperatures at Station $\mathrm{P}$ is narrower $\left(6-14^{\circ} \mathrm{C}\right.$; Figure 6 in Miller et al. 1984) than that at Site $\mathrm{H}\left(2-18^{\circ} \mathrm{C}\right.$, cf. Fig. 2). Station $\mathrm{P}$ is warmer than Site $\mathrm{H}$ in general; temperatures as low as $3^{\circ} \mathrm{C}$ throughout the year are seen only below $1000 \mathrm{~m}$ in the former but below $200 \mathrm{~m}$ in the latter. At Station P, phytoplankton biomass does not show clear seasonality throughout the year (0.1-0.6 mg chlorophyll $\left.a \mathrm{~m}^{-3}\right)$ although primary production reaches its maximum in May to July (Harrison et al. 2004). In contrast, the occurrence of a phytoplankton bloom (2-9 mg chlorophyll $a \mathrm{~m}^{-3}$ ) between March and June is a regular annual event at Site $\mathrm{H}$ in the Oyashio region (Kasai et al. 2001). As an index of the abundance of potential food for $A$. digitale, zooplankton biomass in the epipelagic zone $(0-150 \mathrm{~m})$ at Station P (annual mean; 61 $\mathrm{mg}$ wet weight $\mathrm{m}^{-3}$, calculated from Fig. 7 of Parsons \& Lalli 1988) is much less than that (115 $\mathrm{mg}$ wet weight $\mathrm{m}^{-3}$, Odate 1994) in the Oyashio region. Assuming the wet weight: dry weight ratio of a zooplankton sample is 1:0.12 (Kotori 1976), this wet biomass of epipelagic zooplankton in the Oyashio region is equivalent to $2,070 \mathrm{mg} \mathrm{DWm}^{-2}$ $(115 \times 0.12 \times 150)$ in the top $150 \mathrm{~m}$ water column, which is 11 times greater than that $\left(186 \mathrm{mg} \mathrm{DW} \mathrm{m}^{-2}\right)$ of $A$. digitale in the $0-2,000 \mathrm{~m}$ water column mentioned above. According to Arai \& Fulton (1973), A. digitale at Station P spawn in June-September, and resultant offspring overwinter and spawn the next year (annual life cycle). The maximum size specimens attained was $20 \mathrm{~mm} \mathrm{BH}$. Excepting this smaller maximum size ( $20 \mathrm{~mm} \mathrm{BH}$ as compared with $22.5 \mathrm{~mm} \mathrm{BH}$ of Site $\mathrm{H}$ specimens), the life cycle patterns of $A$. degitale at Station $\mathrm{P}$ are remarkably similar to those at Site $\mathrm{H}$ mentioned above.

Despite dissimilar environmental conditions between Site $\mathrm{H}$ and Station $\mathrm{P}$ mentioned above, similar life cycle patterns seen for $A$. digitale living in these two habitats may be interpreted as a result from opposite effects of temperature and food abundance. That is, the negative effect of lower temperatures on the development of $A$. digitale at Site $\mathrm{H}$ is compensated by the positive effect of higher food concentrations in the same region. As with $A$. digitale, no regional differences have been reported in the life cycle and associated ontogenetic vertical migration patterns of some grazing copepods (Neocalanus spp.) inhabiting Site H and Station P, but the body sizes of specimens at Station P were smaller than those at Site H (Kobari \& Ikeda 1999, 2001a,b) as was the case for $A$. digitale mentioned above.

One generation per year of Aglantha digitale at Site $\mathrm{H}$ and Station P in the subarctic Pacific is also the case for the populations in the North Sea (Kramp 1927) and in the Northeast Atlantic (Williams \& Conway 1981). However, more diverse generation numbers have been documented for local $A$. digitale populations; including two generations per year in Toyama Bay (Ikeda \& Imamura 1996), Ogac Lake of Baffin Island, (McLaren 1969) and the Strait of Georgia (Arai \& Mason 1982), or even three to four generations per year in a Norwegian fjord (Smedstad 1972) and off Plymouth (Russell 1938). Not only the number of generations, but the size at maturity for $A$. digitale has also been reported to be highly variable between different habitats; $4.3 \mathrm{~mm}$ for the population in Ogac Lake, $19 \mathrm{~mm}$ for those living its neighboring open sea (McLaren 1969), and $17 \mathrm{~mm}$ in Toyama Bay (Ikeda \& Imamura 1996). While temperature and food abundance were considered to be environmental parameters affecting the life cycle features of A. digitale in the subarctic Pacific in this study, broad analyses across all the diverse habitats of this medusa should be done to confirm these and identify new environmental parameters of consequence.

\section{Acknowledgements}

We are grateful to two anonymous reviewers for valuable comments. Thanks are due to the members of Plankton Laboratory for their help in field sampling of zooplankton.

\section{Literature Cited}

Arai MN (1992) Active and passive factors affecting aggregations of hydromedusae: a review, pp.99-108. In Aspects of hydrozoan biology (eds. Bouillon J, Boero F, Cicogna F, Gili JM, Hughes RG). Sci Mar 56.

Arai MN, J. Fulton J (1973) Diel migration and breeding cycle of Aglantha digitale from two locations in the Northeastern Pacific. J Fish Res Bd Canada 30: 551-553.

Arai MN, Mason JC (1982) Spring and summer abundance and vertical distribution of hydromedusae of the central Strait of Georgia, British Columbia. Syesis 15: 7-15.

Arai MN, Welch DW, Dunsmuir AL, Jacobs MC, Ladouceur AR (2003) Digestion of pelagic Ctenophora and Cnidaria by fish. Can J Fish Aquat Sci 60: 825-829.

Colin SP, Costello JH, Klos E (2003) In situ swimming and feed- 
ing behavior of eight co-occurring hydromedusae. Mar Ecol Prog Ser 253: 305-309.

González PF, González SR (1996) Diet of the gelatinous zooplankton in Hardangerfjord (Norway) and potential predator impact by Aglantha digitale (Trachymedusae). Mar Eco Prog Ser 139: 69-77.

Harrison PJ, Whitney FA, Tsuda A, Saito H, Tadokoro K (2004) Nutrient and plankton dynamics in the NE and NW gyres of the subarctic Pacific Ocean. J Oceanogr 60: 93-117.

Hirohashi S (1988) Ecology of hydromedusae in the northern North Pacific and Bering Sea, with special reference to the trachymedusae Aglantha digitale (O.F. Müller). MSc Thesis, Graduate School of Hokkaido University (in Japanese)

Ikeda T, Imamura A (1996) Abundance, vertical distribution and life cycle of a hydromedusa Aglantha digitale in Toyama Bay, southern Japan Sea. Bull Plankton Soc Japan 43: 31-43.

Kasai H, Saito H, Kashiwai M, Taneda T, Kusaka A, Kawasaki Y, Kono T, Taguchi S, Tsuda A (2001) Seasonal and interannual variations in nutrients and plankton in the Oyashio region: A summary of a 10-years observation along the A-line. Bull Hokkaido Natl Fish Res Ins 65: 55-134.

Kawamura A (1968) Performance of Peterson type closing net. Bull Plankton Soc Japan 15: 11-12.

Kobari T, Ikeda T (1999) Vertical distribution, population structure and life cycle of Neocalanus cristatus (Crustacea: Copepoda) in the Oyashio region, with notes on its regional variations. Mar Biol 134: 683-696.

Kobari T, Ikeda T (2001a) Life cycle of Neocalanus flemingeri (Crustacea: Copepoda) in the Oyashio region, western subarctic Pacific, with notes on its regional variations. Mar Ecol Prog Ser 209: 243-255.

Kobari T, Ikeda T (2001b) Ontogenetic vertical migration and life cycle of Neocalanus plumchrus (Crustacea: Copepoda) in the Oyashio region, with notes on its regional variations in body size. J Plankton Res 23: 287-302.

Kotori M (1976) The biology of Chaetognatha in the Bering sea and northern North Pacific Ocean, with emphasis on Sagitta elegans. Mem Fac Fish Hokkaido Univ 23: 95-183.

Kramp PL (1927) The hydromedusae of the Danish waters. K danske vidensk Selsk Skr Afd 12: 1-291.

Kramp PL (1959) The hydromedusae of the Atlantic Ocean and adjacent waters. Dana Rep, 46: 1-283.

Kramp PL (1965) The hydromedusae of the Pacific and Indian Oceans. Section I. Dana Rep 1-162.

McLaren IA (1969) Population and production ecology of zooplankton in Ogac lake, a landlocked fjord on Baffin Island. J Fish Res Bd Canada 26: 1485-1559.

Miller CB, Frost BW, Batchelder HP, Clemons MJ, Conway RE (1984) Life histories of large, grazing copepods in the subarctic ocean gyre: Neocalanus plumchrus, Neocalanus cristatus and Eucalanus bungii in the Northeast Pacific. Prog Oceanogr 13: 201-243.

Odate K (1994) Zooplankton biomass and its long-term variation in the western North Pacific Ocean. Bull Tohoku Natl Fish Res Inst 56: 115-173. (in Japanese with English abstract)

Ohtani K (1971) Studies on the change of the hydrographic conditions in the Funka Bay. II. Characteristics of the waters occupying the Funka Bay. Bull Fac Fish Hokkaido Univ 22: 58-66.

Padmavati G, Ikeda T, Yamaguchi A (2004) Life cycle, population structure and vertical distribution of Metridia spp. (Copepoda: Calanoida) in the Oyashio region (NW Pacific Ocean). Mar Ecol Prog Ser 270: 181-198.

Pagès F, González HE, González SR (1996) Diet of the gelatinous zooplankton in Hardangerfjord (Norway) and potential predatory impact by Aglantha digitale (Trachymedusae). Mar Ecol Prog Ser 139: 69-77.

Parsons TR, Lalli M (1988) Comparative oceanic ecology of the plankton communities of the subarctic Atlantic and Pacific Oceans. Oceanogr. Mar Biol Annu Rev 26: 317-359.

Runge JA, Pepin R, Silvert W (1987) Feeding behavior of the Atlantic mackerel Scomber scombrus on the hydromedusa Aglantha digitale. Mar Biol 94: 329-333.

Russell FS (1938) The Plymouth offshore medusa fauna. J mar biol Ass UK 22: 769-809.

Shoden S, Ikeda T, Yamaguchi A (2005) Vertical distribution, population structure and lifecycle of Eucalanus bungii (Copepoda: Calanoida) in the Oyashio region, with notes on its regional variations. Mar Biol 146: 497-511.

Smedstad OM (1972) On the biology of Aglantha digitale rosea (Forbes) (Coelenterata: Trachymedusae) in the inner Oslofjord. Norw J Zool 20: 111-135.

Søreide JE, Hop H, Falk-Petersen S, Gulliksen B, Hansen E (2003) Macrozooplankton communities and environmental variables in the Barents Sea marginal ice zone in late winter and spring. Mar Ecol Prog Ser 263: 43-64.

Tsuruta A (1963) Distribution of plankton and its characteristics in the oceanic fishing grounds with special reference to their relation to fishery. J Shimonoseki Univ Fish 12: 13-214.

Vinogradov ME, Shushkina EA (2002) Vertical distribution of gelatinous macroplankton in the North Pacific observed by manned submersible Mir-1 and Mir-2. J Oceanogr 58: 295-303.

Williams R, Conway DVP (1981) Vertical distribution and seasonal abundance of Aglantha digitale (O.F. Muller) (Coelenterata: Trachymedusae) and other planktonic coelenterates in the northeast Atlantic Ocean. J Plankton Res 3: 633-643.

Zenkevitch L (1963) Biology of the seas of the U.S.S.R. George Allen \& Unwin, London, 955 pp. 